\title{
都市住宅調查と「住むこと」の発見
}

\section{Urban Housing Surveys and the Discovery of 'Home Life' in Modern Japan}

\section{祐 成 保 志 SUKENARI Yasushi}

This paper, as part of study that aims at understanding the characteristics of the modern homes, discusses about urban housing surveys in Japan in the 1910-40s, using a method of historical sociology. Housing surveys can be read as discourses on homes. This paper stresses the fact that those surveys described not only the properties of houses but also the relationship between homes and inhabitants. Those surveyors' perspectives were linked to contemporary discourses on homes. The numerous attempts at housing surveys suggest that the process of formation of modern homes was based on ideas and technologies refined at every moment.

\section{1.はじめに}

デビッド・モーレーは、アン・オークレーの“Housewife”（1974年）から、「家族はます ますその物理的なロケーション、すなわち homeと同一視されるようになってきた。『home』 と『家族』は、いまやほとんど置き換え可能である」という一節を引用しながら、近代イ ギリス社会において、「home中心のライフスタイル」へと向かう大きな流れが存在し、そ れがとりわけ戦後に顕著となったと指摘している。メディア研究者であるモーレーは、 「homeを基盤とした大量消費、そしてありとあらゆる耐久消費財…の所有こそが、このプ ロセスの中核をなした」[Morley 2000:25]と述べ、homeを構成する耐久消費財群の中心に テレビがあった、と論を進める。

本稿の関心は、日本において「home中心文化」[Morley 2000:26]が形成される過程にあ る。もっともここでは、耐久消費財やメディア・コミュニケーション技術のhomeへの浸 透、およびそれらを通じたhomeの構成といった具体的な経緯そのものに即すわけではな い。その序章となる作業として、日本における20世紀前半のhomeについての言説を素材 とすることで、この過程の一局面を捉えたいと考える。

ところで、ここまでhomeという言葉を訳さずに表示してきたのは、この言葉を通例に 従って「家庭」と訳すことで生じる曖昧さ、例えば家族とhomeの置き換え可能性につい てのオークレーの指摘の意義がかえって不明瞭になる可能性があることに留意するためで ある。モーレー自身、この語のもつ多義性を最大限引き出す形で議論を展開している(1)よ うに、homeを一言で訳すことは困難であるが、本稿ではあえて、場所としての性質を明 確にする意味で、これを「住居」と読み換えてみたい。

住居は、単なる物理的な空間としての「住宅」と区別できる。それは身体やモノや意味 まで含んだ社会的領域である。実際、私たちが日常的語法のなかで住居と言うときにも、 
すでに住宅という物の特性とともに、設備や装置が身体によって操作され、逆にそれらに よって身体が相互に関連づけられる場面についての想像を働かせている。住居とは、空間 装置を媒介とした社会的統合のあり方についての想像が投影される場に他ならない。

本稿では、以上のような問題意識から、1910年代から1940年代にかけて生み出されたい くつかの「住宅調査」に着目する。その際、調査を当該時期の住宅の実情を明らかにする ためというよりは、それらを住居に関する言説として扱う。住宅調查は、それがどのよう な主題で実施され、どのようなサンプルが選ばれ、何が記録され、計測されたか、という 各側面において、住居についての言説として捉えられる。また、この時期を選んだのは、 ごく短い期間でありながら、「住むこと」に関わる理念形成、政策化、商品化が著しく進 行しており、社会の空間的編成において住居が中心性を獲得する初期の様相を明らかにで きると考えるからである。

先行研究としては、日本近代住宅調查の歴史を扱った吉野英岐の一連の研究（[吉野 1989;1991;1994]）を挙げることができる。吉野の問題意識は、調査結果よりも調査者の視 点に着目する意味で本稿と重なるところが大きい。ただ、調查史という問題設定の制約を 受けて、住宅調査以外の言説がほとんど言及されていない。ここでは通史的な網羅性を追 求するかわりに、その周辺、あるいは他の領域の言説との関連を重視したいと考える。

本稿の構成は次の通りである。第2節では、民間人によって行われた最初期の住宅調査 として賀川豊彦の貧民住居論を取り上げる。第3節では、行政による調査の一例として大 阪市社会部のモノグラフ的住宅調査に焦点を当てる。第4節では住宅調査の周辺に位置す る都市計画家の言説にみられる、居住者の住居への欲望や感覚を問題化する視点を明らか にする。第5節では、本稿のまとめとして、これらの言説を同時代の社会的文脈のなかに 位置づけることを試みる。

\section{2.「群居」する身体一賀川豊彦の貧民住居論}

タカシ・フジタニは、国家による地方（local）の可視化に関する論考で、「明治のごく 早い時期から、政府のなかには、人口と、土地と、その他あらゆる国内の資源を支配し管 理するうえで重要な関わりをもつ、数字とデー夕を収集し操作しなければならないとする 一つの妄執が存在した」[Fujitani 1994:166]と述べている。

地図作成、人口統計、徵兵に関わる身体検查などを通じた国内資源の把握が進行する過 程で、国土は、その境界の内側が完全に可視化される「監禁の空間」[Fujitani 1994:173]へ と変換されたという。とはいえ、フジタニの記述は明治期に限定されており、可視化の対 象としては「土地」と「人口」が挙げられるのみである。土地と人口の間に広がる「生活」 という領域の可視化は、いまだ手付かずであった。ようやく明治末期、下層労働者と都市 下層民の生活が調査対象に据えられるようになる。この変化と関わる政治史上の事件とし て、内務省地方局を中心とする「地方改良運動」を挙げることができるだろう。

日露戦争後、1890年代に一応の確立を見た日本の近代国家体制が示しはじめた機能不全 への対応として、民衆の「エネルギーの原点にまで下降接触し、それによって政治の面目 を一新すべきであるという発想」[橋川 1993:136]が主として内務官僚の間に生じた。「日 比谷焼き打ち事件」のように、騒擾という形態をとれば体制への脅威となるかもしれない 民衆の潜在的な力を測定し、育成し、国家の充実に結び付けようとした。このとき唱導さ 
れた改良の対象領域としての「地方」の意味内容は、現在のそれとの間に大きな隔たりを もっている。後に「今日盛んに行わる、社会改良事業は実は此の時に開かれたるなり」 [井上会1940:14]と回顧されるように、地方という概念の中に盛り込まれた課題は、端的に 「社会」であり「生活」であった。

もっとも、明治の地方改良があくまでも農村部を主たる舞台とした精神運動であったこ とは否定できない。そのことは、都市問題への対応を軸に、広大な領域にわたって西欧に おける事例を紹介した内務省地方局有志『田園都市』（1907年）が、結局のところ「[日本 の]多くの都市は自ら田園の趣を帯びざるなし」と結論づけ、日本的伝統の美風としての 「田園生活の精神」が問題の解消をもたらすであろうという予定調和的観測を述べるにと どまっていたことからも確認できる。

ただ、『田園都市』にはいくつか住宅の改良に関する言及を見出すことができる。いま た一般論にとどまっているとはいえ、ここで、「良き住宅一良き家庭一良き人格」、そのネ ガとして「悪しき住宅一悪しき家庭一悪しき人格」という図式が提示されていることは注 目しうる。

剛健なる精神は健全なる家庭に宿り、健全なる家庭はつねに整頓せる住居のなかに形成せらる。 されば良民をつくるのみちは、まず家庭を改良するにあり、家庭の改良はまた実に住居を斉うる をもって第一義とす。…ただ従来はもっぱら衛生の見地よりして、これに注意したりしに、いま は進んで国民の風化を進めんとの見地よりして、同じく力をこの事業[住宅改良]に用ゆるもの所 在ようやく多きを致せり。[内務省地方局有志 1907 $\rightarrow$ 1980:99]

地方改良理念に先導されながら、内務省地方局「細民調査」（1911年）を端緒として行 政による都市の生活観察が調査機関の整備を通じて組織化されはじめる。ただし、そうし た調査と互いに引用参照しあう、民間の観察者による調査が存在したことを見落としては ならない。そこに調査に対する問題意識がより明暸に表れているという意味で、検討に值 するものである。

神戸のスラム街に住み込んで貧民救済活動を展開していた社会事業家・賀川豊彦による 報告『貧民心理の研究』(1915年) の中で「住宅問題」と題された項は、「もう凡ては悲哀 のかたまりである『二畳敷』に落ちたが最後、人間としての品位は全く無いのである」 [賀川1915:217]という言葉で始まる。「二畳敷」とは、棟割長屋を構成する二畳一間の部屋 のことである。住宅問題に関して、狭さや構造の欠陥、不衛生と不便が指摘されているだ けでなく、「貧民がその住宅の設備の不完全によって種々なる方面に人格を失って居るこ とは甚しい」[賀川 1915:222]と、その核心が「品位」「人格」「道德」の問題として捉えら れていることに注意したい。

賀川は告発する。貧民窟においては、あるべき身体間の距離が欠如している。「凡てが 共同的であり、家にあっては狭い家に、父の衣服と子供の衣服が共同、妻の帯と主人の帯 が共同であるので、ついつい共同人格というものが出来上が」[賀川1915:222-223]る。そ れは愛情に基づく家族の一体感とは無縁のものであり、信頼に基づいた親密さなどではな く即物的な接触にすぎない。「家庭に慰安があるで無く、結合や責任があるのではない。 貧民生活は全くの無家庭生活である」[賀川 1915:469]。 
彼によれば、「共同人格」にしろ「結合や責任の不在」にしろ、それらは「二畳敷」と いう環境から導かれる必然である。貧民の索漠たる内面、精神の貧困は、先天的な属性で あるよりは居住形態から派生したものとされる。賀川が1919年、建築学会において行なっ た講演「貧民の生活状態に就て」では、「群居」[賀川 1919a:171]の荒廃が、より鮮烈に描 写される。「二畳敷の所へ持って行って九人くらい寝て居る」[賀川1919a:170]ところでは、 性道德は失われてしまう。「貧民窟に於きましては『寝た者夫婦』と云う一つの法則があ ります」[賀川 1919a:171]と、聴衆である建築家たちに対して惨状を訴える。

賀川は、貧民窟が全くの無秩序の空間であったと述べているわけではない。無家庭生活 が不幸の絶対的な条件でないことは、彼自身強調するところであり、貧民窟をアジールと も言うべき「逃亡市」[賀川 1915:229]と呼び、「二畳敷などでは少し天気が善いと皆、通 に出て仕事をしているから皆笑い叫んで、己の生活を悲観して居るものなどは殆ど無い」 [賀川1915:229]と、その底抜けの明るさに感嘆の声さえ上げている。しかし、貧民窟の秩 序である「集団道徳」[賀川 1915:471]を支える仕組みは冷静に観察される。貧民窟は、あ る面では貧民にとって好ましい環境であり、また必要に応じた生活の方法の集積体であっ た。たからこそ、それは改良されねばならない。貧民窟が生み出し、そこに安住してしま うような心理や人格が問題となるのはこのためである。

そこで、「貧民窟が一個の単位でないように」[賀川 1919a:172]改造することが戦術的な 課題となる。賀川は建築家に要望する。「唄民窟で群集して居っては群集心理に支配され

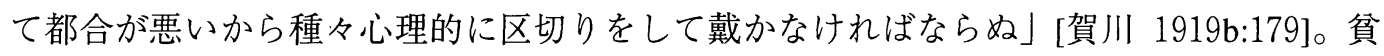
民生活の諸特徵は貧民集団の中での「区切り」の不在によって生じる。彼が求めるのは、 建築的解決によるこの悪循環の切断であり、適切な区切りとしての住居の形成と維持、す なわちしかるべき場所への空間の分割と身体の定着を可能にする空間の設計であった。

建築学会都市計画委員は、1918年から19年にかけて、賀川の協力を得て神戸のあるスラ ムの実態調査を行っている。この日本建築学史上における最初期の実態調査を経て示され た対策案では、建築的な配慮がより詳細なものとなっている。いたるところに「隔壁」を 設け、通り抜けを防止し、街路構造を単純化する。览童遊戯のための小公園を、地区の奥 まったところではなく街路に近いところに設置する。街路や大通りから地域内の小通路へ の見通しを遮るような障害物を取り除く、等々。これらの具体的提案から読み取ることが できるのは、筫民を見えやすくすることによって外から管理しやすくするだけでなく、貧 民自身に見られていることを意識させること、そしてそれを通じて彼らが住居を構成する 術を身に付けることが必要であるとの認識である。

賀川ら初期住宅調査者は貧民窟における特異な生活を発見した。しかし、それだけなら ば、「良民」と大きくかけ離れた生活が描写されていた明治中期の貧民窟「探検」記(2) と 大きく変わるところはない。決定的な違いは、「無家庭生活」や「共同人格」といった特 異な生活が、住居の不在としての「群居」から生じるものと捉えられているところにある。 探検という姿勢を支える視点は、環境と、そこに住む人々との「相即」に他ならなかった。 そこでは、貧民窟はあたかもそれ以上分割不可能な一塊の異世界のように捉えられ、貧民 の生活は貧民窟という場所と分離不能な貧民という一種族の習性、宿命あるいは治療不能 の病として認識されてしまう(3)。その視点は、1880年代の市区改正論において主流をなし た貧民隔離論(4)とも呼応するであろう。これに対して、賀川らは住居と人格の相関につい 
ての認識を経ることで、追放や事後的・応急的救貧とは異なった構想を導き出したのであ る。

\section{3. 住宅調査という方法一大阪市社会部報告から}

「住宅調査」と題する独立の調査が、行政の関与のもとに組織的に行われるようになる のは1920年代である。1920年、内務省に社会事業、労働行政の統轄機関として社会局が設 置される。これに前後して地方当局においても社会事業を担当する部門が開設され、1921 年には3府19県10市、1928年までには全道府県に設置された[吉野 1991:196]。これらの部 門が主体となって、1920年代以降、生活調査が大規模に実行されるが、その際に採用され る方法の大きな柱となったのは、貨幣を媒介とする生活観察、すなわち単位としての世帯 に貨幣が出入りするときにあらわれる構造性の把握をめざす「家計調査」である。そこで は、獲得され使用される貨幣の量とともに、使い方が調査項目となった。

ここでは、生活調査のもう一つの柱として、未発達ながら「住宅調査」という方法があ ったと考えたい。世帯が形成され、形成する空間（「住宅」「住戸」、ときにはそれらの集 合体としての「地区」）に焦点が当てられ、それらのモノとしての属性とともに、使い方 (「居住の方法」あるいは「住み方」) 功調査項目となる(5)。実際、大阪市社会部が実施し た『住宅調査』(6)（1919年調査実施、1921年報告書刊行）では、「生計調査は非常に包括 的なものであって、消費者としての労働者の生活の全般の鳥瞰図である」[大阪市社会部 1921a １976:1]のに対して、生活状態をより詳細に明らかにするためには生活の場である 住宅の現状の分析が不可欠であると、その独自の意義を強調している。

この調査では職工と教員という異なる階層を対象として比較が行われた。例えば教員で は同居者数と総睍数の大小がほほ釣り合っているにもかかわらず、職工においては、畳数 が少ない住宅ほど、逆に同居者数が多くなるという傾向が観察された。報告によれば、そ れは単なる職工の経済的貧困の反映ではなく、職工の「文化的欲望の薄弱」[大阪市社会 部 1921a $\rightarrow 1976: 24]$ 関わる。『住宅調査』は、階層間の比較によって、その住宅への意識 や態度の差異を発見し、職工のそれを貧民窟の住人に近いものと診断した。

一方、『常傭労働者の生活』(1921年調査実施、報告刊行) は54事例から構成されるモ) グラフである。『住宅調査』では職工は一括して扱われていたが、この調査では工場労働 者のなかにおける意識や態度の分化を指摘している。報告の中で、住宅に関する記述が少 なからず登場する。そのいくつかを基礎的なデー夕とともに再構成した。

\section{A 伸銅所職工 · 35 歳 $\cdot$ 家族 4 人 $\cdot$ 月収 80 円 $\cdot$ 家賃 10.4 円}

「家中の様子が実に整然として居る。主人の工夫で出来た天井の棚には種々の品物が正しく置か れ、神棚も小さな箱ではあるが、主人の座席に対して立派に出来て居る。主人の家族に対する態 度は、親切を極め、妻君も忠実に働くらしい。」[大阪市社会部 1921b $\rightarrow 1977: 3$ ]

B 伸銅所職工・ 29 歳・家族 4 人 · 月収 120 円・家賃 15 円・二階6畳を間貸し

「玄関は堂々たるもので家の間取りは二階六畳二間下二畳二間に四冨半…。整頓等は手に入った もので労㗢等をしている人の家だとは思えない程に立派である。」[大阪市社会部 $1921 \mathrm{~b} \rightarrow$ 1977:23-24]

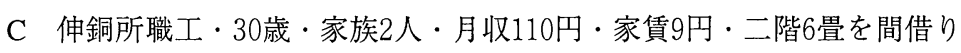


「全く官吏会社員と云う種類の人が住む様な作りで・..此家に伸銅所に通って居る人が居るとは思 えなかった」[大阪市社会部 1921b $\rightarrow$ 1977:37]。

D 電燈会社職工 $\cdot 26$ 歳・家族 3 人 $\cdot$ 日収 1.6 円 ·家賃 9 円・二階 4 畳半 +3 畳を間借り

「部屋の中は美しく整頓せられて居り、妻君も髮を近代的の女優䰄に結って頗る気持ちがよい。 …室内装飾も立派なり、諸道具も整然と置かれてある処から見てとても一円六十銭の日給で生活 して居る人とは思われない。」[大阪市社会部 $1921 \mathrm{~b} \rightarrow 1977: 95$ ]

E 市電倉庫助手 $\cdot 56$ 歳・家族 3 人 $\cdot$ 日収 2.15 円 $\cdot$ 家賃 8 円

「二階六畳、下三畳に二畳である。…彼の家は非常に清潔である。こ扎は彼が細工好きだから何 もかも整頓し又色々と細工をして居るからで器の如きも一々研ぎをかけて居る。」大阪市社会 部 1921b $\rightarrow 1977: 155]$ 。

調査者は、実際に訪れた住居に関して、予断が妥当しないことに対する驚きを隠さない。 ただし観察されたのはこのような住居ばかりではない。

$\mathrm{F}$ 紡績会社職工・29歳・家族 2 人・月収 50 円（共稼ぎ）・家貨 2 円（社宅）

「大抵の貧民窟もこんなに污くはない。…玄関が三畳で奥が四畳半である。電燈は一䇢、玄関の土 間が同時に台所の土間となって居る…、排水が不完全なので雨が降れば裏の溝から污水が流れ込 んで来る」[大阪市社会部 1921b $\rightarrow$ 1977:53-54]

G 電燈会社職工 $\cdot 30$ 歳 $\cdot$ 家族 3 人 $\cdot$ 月収 100 円弱 $\cdot$ 家貨 9.8 円

「何十軒と云う長屋に水道は僅かに一個であり便所も共同便所である…周囲の状態は陰惨と不潔 の二字に尽きている。」大阪市社会部 1921b $\rightarrow 1977: 104]$

$\mathrm{H}$ 市役所土木部人夫 $\cdot 42$ 歳 $\cdot$ 家族 5 人 $\cdot$ 日収 1.55 円・家賃 6 円 $\cdot$ 二階を間借り

「階六盢二間に下六盢四畺半六畳」の長屋のうち、二階六盢に本人一家が住む。一階の手前の六 畳には夫婦、奥の四畳半には家主一家がおり、親族関係のない三家族が同居している。「『只もう 少し収入が多ければ』とは云うのではあるが誰も云うから自分も云って見たという調子で心から 現在の境遇に満足して居るものの如くである。」大阪市社会部 1921b $\rightarrow 1977: 185$ ]

このモノグラフは、労働者の内面（interior）を住宅内の光景（interior）の記述を通して 描き、階層間の比較に代わって、階層内で分化しつつある住宅への意識や態度を問題化し た。すなわち、大阪市社会部が1920年前後に実施した二つの調査は、住居を居住者の意識 状態の「相関項」として捉えるという意味で同一の視点から構成されていた。それはまた、 都市計画家にも共有されていたものである。

\section{4. 居住する方法/住居への欲望一都市計画家の視点}

大阪市社会部の住宅調査を参照しながら、社会政策学者・関一は、「成功を夢みて都市 に集合する無産者階級は住居状態に関しては全く無関心」[関 1923:20]であると指摘した。 関は警告する。とりわけ注意すべきは、貧民窟に入り达んた「落伍者」の群れである。 「恒産なく恒心なき貧民窟住民こそ、異日万一米騒動の如き不祥事の突発する時は忽ち暴 民化する階級である」[関 1923:22]。明治の地方改良論者が「日比谷焼き討ち事件」に戦 慄したように、大正の社会政策論者は「米騷動」の再来を恐れる。関において、都市街頭 
における騒乱は、住居への欲望の欠如と深く関連するものと捉えられている。

こうした問題意識のもとに、関は住宅政策の必要を唱え、具体策の一つとして「住居法」 の制定を主張する。住居法の規制範囲は「市街地建築物法」（1919年制定）のような建築 物としての住宅にとどまらない。「其監督の目的物は家屋と云う人格なき物でなく、居住 者なる人であることを忘れてはなら関 1923:48]。ちょうど同時期に整備されつつあ った「方面委員」のごとく、地域有力者を監督者として組織することによって、都市住民 の「居住する方法」についても制限を加えようとする。関が構想したのは、診断（監督組 織、住宅調査）・治療（住居法）・予防（公的住宅供給）の循環に他ならない(7)。

行政当局者の発言にも、関と類似の主張を数多く見出すことができる。例えば、大阪市 や東京市、あるいは同潤会などによるスラム改善を促進する立場にあった内務省社会局・ 清水虎雄は、都市下層の住宅問題は賃金などの経済的問題ばかりでなく、「生活への欲望」 の問題から発するものであることを強調する。「細民の衣服及住居に対する欲望は食欲の 如く熾烈なるものではない。飲酒欲、肉欲、賭博欲の方が之より強」く、「住居欲が低い 為、住居の管理が極めて不完全」[清水 1933:5]であるとすれば、改善を要するのは収入の 量というより支出の質であり、自己の生活を管理する能力と技術である。「彼等の住居に 対する欲望を向上せしむるにあらざれば仮令収入の増加を計っても住居の改善を期するこ とは困難である」[清水 1933:5]。そして、「暴動の発生地」[清水 1933:6]としてのスラム が、「住居欲」の低劣さによって維持されていると結論する。

「都市計画法」（1919年制定）は、適用区域の計画図面を「住居地域」「商業地域」「工 業地域」「未指定地域」に塗り分け、局所としての土地を「機能」にしたがって再定義し、 全体としての都市のなかに位置づける。こうして都市は「余白のない密な空間」[中川 1985:177]として認識される。住むに適する場所としての「住居地域」の指定は、住むに 適さない場所に展開される生活、あるいは住むに適さない住宅の存在を際立たせる。

1920年代より、集住する人間の性質から規定される「貧民窟」「細民地区」に代わって、 装置的条件からの規定である「不良住宅地区」という行政用語が流通するという現象は、 このことと関わっていると考えられる。まず、住宅という同種の物として比較することに よって「良/不良」の判断が行われる。それだけではない。この用語には、都市下層を、 不良住宅を生産する者であると同時に、それを通じて再生産される者と捉える視点が含ま れている。こうした認識が都市計画と結びっくとき、都市の下層民に対して、「地区改良」 という政策手法が実行される条件が整う。そして、住居と人間の「悪循環」を断ち切った かどうかが検証される(8)。

行政による住宅調査は1930年代後半以降、したいに大規模化し、統計調査としての洗練 度を高めている[吉野 1994]。その一方で、建築学者らによる詳細な事例研究も発表され るようになる。こうした動きには、労働者向け住宅の大量供給が政策的課題とされ、供給 を効率化するための標準設計と、根拠となる実態調査の必要性が認識されたことが関連し ている。

この時期の事例研究の代表的なものとして、建築学者・西山外三(9)による「住み方調査」 がある。「夫婦就寝室の隔離に関する就寝慣習」[西山 1943a $\rightarrow 1967$ ] 題する報告で、西 山は、夫婦と子供が同室に就寝するという要改善状態を「混寝」と名づけ、その出現要因 を分析した。ここで注目すべきは、住宅の狭さと不適当な間取りが「集約就寝」と「混寝」 
を強制していると述べる一方で、それらが住宅の物理的構造の反映であるとともに、居住 者による関心の構造の反映でもあると指摘しているところである。職業層別の分析では、 「混寝」率の大小が「居住者の精神的・物質的な生活水準の順位」[西山 1943a $\rightarrow$ 1967:246] として解釉されている。寝方の違いから、身体のふるまい、および空間への意味付けが階 層によって異なることが見出されたのである。

西山の住宅計画論の特色は、「住宅形式」と「居住慣習」(住み方) の関係を考えること、 そしてそれらを媒介する位置に「住居観念」を置くという点にあった。彼が戦時期におい て提示した構想群は、住宅の生産・供給・消費にわたる包括的かつ体系性を目指したもの であったが、そこでは常に慣習と観念の問題が念頭におかれていた(10)。西山は、慣習が 住宅形式そのものに誘導されて変化すると説き、住宅の供給こそ、「あらゆる教化よりも 直接に住居慣習の改善向上に役立ち、これを現実化する」[西山 $1943 b \rightarrow 1968: 82$ ] と主張し た。このような発想は戦後、本格的に受け入れられ、大規模な供給経路を獲得することに なる。

1951年に登場した、二つの寝室に加えてテーブルとイスが置ける若干広めの台所をもっ た「2DK」と呼ばれる標準設計(11)の開発者の一人である建築学者・鈴木成文は、西山の 住み方調査に触発されながら、敗戦直後の時期、京浜の工場労働者街において数々の調査 を行った（[鈴木 1971]参照）。その過程で、西山が関西の大都市で見出したのと同様に、 居住者が「食寝分離」(食べる部屋と寝る部屋の分離) という住み方(12)を求めていること が再確認されている。2DKはこの要求に応え、最小面積の中で食寝の空間を分離しつつ混 寝を避けうる設計であった。

この一連の経緯は、調査と要求の把握に基づく合理的設計の提示と再調査による改良を 軸とする建築計画学が成立する時期のエピソードとして著名である。しかしながら、後に 鈴木は、建築史家・藤森照信によるインタビューのなかで、その食寝分離という住み方が 実のところ一割足らずの世帯で確認されるにすぎなかったと告白している。

むしろ例外として切り捨ててもいいくらいだった。だけども、それ[食寝分離]をやってる家の人 と話していると、みんな住むことにとても意欲的でいろんな工夫をしているんだ。‥この一割の側 に未来が見えた。この辺の判断は…直感に近い。[藤森 1990:288]

鈴木は、居住者の「意欲」との関連で住み方に着目した。「ひたすら工業労衝者街を歩 き、戸別訪問しては住生活の実態を見、また居住者と話しこむことの中から、その住生活 上の要求を把握することに努めた」[鈴木 1971:3]という鈴木の住宅計画論は、要求と現実 の矛盾のなかにプランの根拠を求めるというものであったが、矛盾は、必ずしも多くの居 住者に認知されているわけではない。住むこと、すなわち住居という空間の形成に意識的 な層と意識的でない層が存在するなかで、調査者・計画者としての建築家の役割は、意識 的な層の要求に準拠し、意識的でない層の自覚を促すことに置かれる。

戦時期の住宅計画論のなかには、西山の「住居観念」以外にも、労働科学の立場から事 例研究を行った岡島暢夫の「居住概念」[岡島 1941]のような、いささかぎこちない言葉 を見いだすことができる。それらは、いわば「観念としての住居」「概念としての居住」 という視点にもとづいて作成され、用いられている。こうした概念は戦後において「住意 
識」という言葉に集約されていくわけだが、それもまた住宅についての意識だけでなく 「住むという意識」という水準にもう一つの焦点があると考えられる。すなわち、「住むこ との意識化」という課題に対応して鈴木の「直感」は働いていた。それはまた、住宅によ る啓蒙の効果について言及した次のような日本住宅公団の自己評価と通じ合う。

公団住宅の持つ特色[間取りやシステムキッチン、シリンダー錠、鉄扉、風呂などの設備]が、 こうした意味で日本の庶民の暮しの中の近代的な意識を成長させてゆく道具立てとなったという ことは、ここで評価してみる価値がある。[日本住宅公団 1965:138]

\section{5. 結び一「相関項」としての住居}

ここでは本稿のまとめとして、住居についての同時代の言説を概観することで住居とい う「相関項」が意識される条件とその意味について考察したい。

1920年前後、人工物を中心とするマテリアルな環境が人格に与える作用に着目し、人格 とモノの相関に言及する「文化生活論」が、都市の知識人に大きな影響を与えた（[加藤 1990]; [神野 1994]など参照)。「平和記念東京博覧会」（1922年）において、「文化村」と題 された企画がモデル住宅の展示を中心として行われたように、文化生活の核には「文化住 宅」があり、住宅の改善を欠けば実現できないとされた。日常生活への関心の高まりと改 善熱のなかで、建築家だけでなく、幸田露伴、内田露庵など多くの知識人などが住宅改良 への意見を寄せた住宅専門雑誌『住宅』(1916年発刊) が、一定の読者を獲得する(13)。

1920年代後半から1930年代、住居への欲望は通俗化しながら広がりを見せ、新中間層に 向けた婦人雑誌には、住宅入手のためのマニュアル的な記事の他に、入手までの過程を手 記の形で描いた読者投稿が数多く揭載されるようになる。「建てた方でなければ味わうこ とのできぬ、自分の生甲斐と強さとを、しみじみと感じます」[鈴木1929:151]というよう な感慨が定型化され、住居は、単なる空間的境界線としてではなく、居住者の確かな生活 を雄弁に物語る社会的境界線として描かれる(14)。

紙の上ばかりではない。1930年代前半を戦前期のピークとして、建築家団体、マス・メ ディア、電鉄資本・百貨店などは、現物や模型を展示する「住宅展覧会」を盛んに開催し ていた。雑誌記事が、住宅論を読む読者がいなくては成立しないように、見せるための住 宅は、住宅を見る観衆の存在を想定する。住宅についてのストーリーを読むこと、そして 都心の百貨店や郊外の新興住宅地に出かけて住宅展覧会を見ることは、一つの娛楽のジヤ ンルとして経験されつつあったと言えよう(15)。雑誌や展覧会といったマス・メディアを 舞台として論じられ、見世物となることを通じて、住宅は居住者の身体と強く結びつけら れる形で、いわば完結した小宇宙である住居として構成されてゆくのである。

住居についての言説の増大は、近代日本に限られた現象ではない。例えば、19世紀後半 から20世紀初頭のシカゴにおける理想的住居についての論争を分析したグエンドリン・ラ イト[Wright 1980]が、論争に関わった建築家、主婦、フェミニスト、社会批評家、資本家 の間で、環境による「感化」や建築の持つ「成形力」(molding power) への信念が共有さ れていたと述べているように、住居という相関項への着目は、近代化の内実を示す一定の 普遍性をもった出来事だったのではないだろうか。

アンソニー・ギデンズは、近代性の特質の一つとして「脱埋め込み」を挙げている 
[Giddens 1990=1993]。住居に関連する場面においては、空間から住居、住居から身体、と いう二重の脱埋め込み過程が進行していた。たからこそ、「住むこと」が改めて見出され、 分離された空間、住居、身体という要素を再び結びつけ、それらの「相関」について論じ る視点が定着したと考えられる。

たたし、そのような過程はマス・メディアにおいてのみ進行していたわけではない。賀 川豊彦は「群居－無家庭生活－悪しき人格」の相関の連鎖を貧民窟の再生産構造として分 析し、大阪市のモノグラフは居住者によるインテリアへの配慮の深さと生活意識の分化を 関連づける。また、西山外三は図表化と図面化の技法を駆使して間取りと身体の関係を数 量化、視覚化しようとした。いずれの住宅調査も、住居という相関項の存在を、理想化さ れたモデルとしてではなく観察された現実として提示していた。

そうして観察者によって内部構造が精緻に描かれれば描かれるほど、逆に観察の視点か ら欠落していったのは住宅の壁の外部である。住宅は、単に建築的な完結性だけでなく、 賀川の言う「心理的区切り」としての性質を備えた住居でなければならなかった。住宅調 査においてもっぱら区切りの内側だけが記述の対象として構成されたのは、調査を駆動し ていた問題意識が住居形成への意志によって裏打ちされていたからに他ならない。モーレ 一の言う「住居中心社会」に向けて技術やモノが配置されていく基盤となったのは、こう した言説の秩序だったのではないだろうか。

注

（1）マス・メディアによる国民文化や郊外文化の構成といったテーマの他に、ホームレス、難民など home中心社会において周縁に位置づけられた人々についても論じている。

(2) 桜田文吾「貧天地飢寒窟探険記」（1890年？[西田編 1949];[中川編 1994]）など。

（3）建築学会の調查報告には、案内役の賀川が、語彙やアクセントを根拠に貧民窟の住人が異人種に起 源を持つことをほのめかし、調査メンバーもそれを追認する場面がある[田村・久留 1919]。そこに は、貧民＝種族説を内包しながらも、建築環境を通じた改良の効果を論じる、過渡的言説としての曖 昧さがある。

（4）市区改正構想の端緒の一つとされる「東京中央市区画定之問題」（1880年）において、東京府知 事・松田道之が提唱したのは、商業地区の囲い込み、皕富の住み分け、不燃化であった。この住み分 けという計画を支えるのは、東京における火災の頻発と伝染病に代表される衛生問題の原因が「筫富 雑居」にあるという認識である[藤森 1990]。

（5）もっとも、貨幣の使い方と比べた場合、空間の使い方を把握することは困難であり、住宅に関わる 調査のなかで最も大きな部分を占めるのは「家賃調査」であった。

(6) 調査対象は職工7,847世帯 37,701 人（一世帯当たり4.8人)、小学校教員 1,274 世帯 5,076 人（一世帯当 たり 3.98 人）で、市内の工場法適用工場職工の内 $29 \%$ 、市内全小学校教員の内 $56 \%$ を占める大規模な ものであった。

(7) 同様の見解は、内務官僚が中心となって結成した「都市研究会」の代表的人物である池田宏も展開

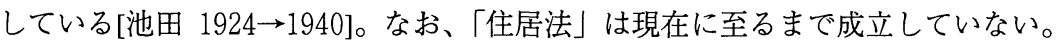

（8）大阪市は1927年から42年までに、天王寺区、浪速区などに分布する不良住宅地区の改良を実行した。 その規模は全国で最も大きい。事業継続中に発表された調査報告『改良住宅に於ける居住者の状況』 （1937年）は、改良の前後を比較し、家賃納入状況、一戸当たり居住世帯数、一戸当たり居住人員数 において、改良がいずれも一定の効果を挙げたことを示している。

(9) 住宅営団研究員などを経て戦後長らく京都大学教授を務めた。その間一貫して実証的な住宅研究を 行い、建築計画学の確立に大きく貢献した。 
(10) 吉野は「住宅調査は大規模化しセンサス化していく過程で、センサス調査特有の無機質的く中立 性>を獲得した」[吉野 1994:179] と述べている。ただし、そ机らは西山外三らの事例研究と相互に補 完的なものである。例えば西山は、大邸宅からスラムまでを労働力の再生産という機能を満たす「住 居」に還元し、それらを置き換え可能な単位空間として設定した。このような視点の獲得が、戦後、 住居の博物誌と言うべき『日本のすまい』（1975～1980年）に結実することになる。つまり西山は、 個々の身体のレベルで「居住慣習」や「住居観念」に着目すると同時に、そうした身体が移動・定着 する過程としてのハウジングの空間を見いだしていた[祐成 2000]。住宅センサス調査が、このハウ ジングのレベルに準拠することは言うまでもない。

（11）DKはダイニング・キッチンの略。1951年、公営住宅基本設計として登場、1955年、日本住宅公団 が若干の変更とともに採用して以来、一般名称となった。

（12） 1940年前後には、永野順造『国民生活の分析』(1939年)、安藤政吉『国民生活費の研究』(1943年)、 篭山京『国民生活の構造』(1943年)、大河内一男編『国民生活の課題』（1943年）など、生活研究史 上重要な業績が、数年のうちに現れている。生活研究者は生活に一定の慣性的な構造を見出し、この 構造が崩れるとき重大な人的資源の消耗が生じると主張した[生活研究同人会1982]。戦時下における 生活諸条件の切り下げに直面して、身体がもつ弾力性の限界というべき「生活構造」が逆説的に見出 された。西山の住み方研究や「食寝分離」論もまた、この身体の弾力性の限界に照準している。

（13）『住宅』は洋風住宅専門の建築会社「あめりか屋」を興した実業家・橋口信助が中心となって設立 した「住宅改良会」が発行していた雑誌である。企業広報誌の性質をこえて大正期住宅改良運動の中 心的役割を担った（[内田 1992]など参照）。

（14）住居と居住者の強固な心理的結びっきが主題となるなかで、住宅にとり憑いた前住者の因縁がもた らす恐怖が語られる。「妖怪秘話恐ろしい家に住んだ実話」(1927.7)、「魔の家に住んだ恐しい実話」 (1928.7）など（ともに『主婦之友』の読者投稿特集タイトル）。

(15) 吉野は、家貨調査が多くを占めた大正期の住宅調査について、「行政の実施した住宅調査でさえも、 住宅が商品として扱われたことは、住宅を生活の場である『すまい』として捉えることができなかっ たことを端的に表している。[吉野 1991:201]と述へ、「すまい」を商品化と対立するものとして論じ ている。しかし、住宅に関わるメディア・イベントが示唆するのは、まさに生活の場である住居その ものが根底的に商品化されるという事態である。

※引用文中における旧かな遣いと旧漢字は、新かな遣いと新漢字に置き換えた。引用文中の[ ]は引用者 注、…省略を示す。

※本稿は、文部科学省科学研究費補助金による研究成果の一部である。

\section{文献}

藤森照信 1982 『明治の東京計画』岩波書店

1990 『昭和住宅物語』新建築社

Fujitani, Takashi, 1994 「近代日本における権力のテクノロジー：軍隊・『地方』・身体」（梅森直之訳） 『思想』845号 岩波書店

Giddens, Anthony, 1990, The Consequences of Modernity, Polity Press（=1993 松尾精文 - 小幡正敏訳 『近代とはいかなる時代か?』而立書房）

橋川文三 1993 『昭和維新試論』 朝日選書

池田宏 1924 『都市住宅問題』 $\rightarrow 1940$ 宮沢小五郎編『池田宏都市論集』池田宏遺稿集刊行会

井上会 1940 『井上博士と地方自治』 全国市町村会

神野由紀 1994 『趣味の誕生：百貨店がつくったテイスト』 勁草書房

賀川豊彦 1915 『貧民心理の研究』警醒社

—1919a 「筫民の生活状態に就て」『建築雑誌』（1919.4）

$1919 b$ 「建築と心理」同上 
加藤百合 1990 『大正の夢の設計家』 朝日選書

Morley, David, 2000, Home territories: media, mobility and identity, Routledge

内務省地方局有志 1907 『田園都市』 $\rightarrow 1980$ 『田園都市と日本人』 講談社学術文庫

中川清 1985 『日本の都市下層』勁草書房

——編 1994 『明治東京下層生活誌』岩波書店

日本住宅公団 1965 『日本住宅公団十年史』日本住宅公団

西田長壽 1949 『都市下層社会：明治前期労働事情』生活社

西山外三 1944 『国民住居論放』伊藤書店

— 1943a 「夫婦就寝室の隔離」 $\rightarrow 1967$ 『住宅計画』著作集1 勁草書房

1943b 『住宅問題』 $\rightarrow 1968$ 『住居論』著作集2 勁草書房

岡島暢夫 1941 「建築技術上より見た住宅問題：居住概念誘導発展の手段として見た住居建築」『社会政 策時報』(1941.7) 協調会

大阪市社会部 1921a 『住宅調査』労働調查報告7号 $\rightarrow 1976$ 大阪市立図書館市史編纂所編 『労働調查

報告復刻版』4巻

— 1921b 『常傭労㗢者の生活』同上16号 $\rightarrow 1977$ 同上5巻

—— 1937 『改良住宅に於ける居住者の状況』同上 222 号 $\rightarrow 1996$ 近現代資料刊行会編 『大阪市社会 部調查報告書』 47

祐成保志 2000 「ことばのなかの住居」『ソシオロゴス』24号 ソシオロゴス編集委員会

鈴木成文 1971 『集合住宅住戸』吉武泰水（編）建築計画学6 丸善

鈴木よし子 1929 「東京の郊外に六百円の家を建てた経験」『主婦之友』(1929.4）主婦之友社

生活研究同人会編 1982 『近代日本の生活研究: 庶民生活を刻みとめた人々』光生館

関一 1923 『住宅問題と都市計画』弘文堂書房

清水虎雄 1933 「不良住宅地区改良事業」『社会事業』(1933.3)

田村鎮 · 久留弘文 1919 「神戸に於ける細民住居視察報告」『建築雑誌』(1919.4)

内田青蔵 1992 『日本の近代住宅』鹿島出版会

吉野英岐 1989 「明治期の住宅調査」川合隆男編『近代日本社会調査史』I 慶應通信

- 1991 「大正期の住宅調査」同 II

1994 「昭和戦前期の住宅調査」同 III

Wright, Gwendolyn, 1980, Moralism and the model home: domestic architecture and cultural conflict in Chicago, 1873-1913, The University of Chicago Press

(日本学術振興会特別研究員 